\title{
Panel Granger Causality between Bank Efficiency and Market Concentration in the European Union
}

\author{
Cândida Ferreira ${ }^{1, *}$ \\ ${ }^{1}$ Lisboa School of Economics and Management, University of Lisbon and UECE, Portugal \\ *Correspondence: Rua Miguel Lupi, 20, 1249-078 - Lisboa, Portugal. Tel: 351-213-925-80 \\ E-mail: candidaf@iseg.utl.pt
}

Received: November 20, 2013 Accepted: January 14, 2014 Published: January 31, 2014

doi:10.5296/rae.v6i1.4589 URL: http://dx.doi.org/10.5296/rae.v6i1.4589

\begin{abstract}
This paper seeks to contribute to the literature with the test of the panell Granger causality relationship running not only from bank efficiency to bank market concentration, but also the reverse causality from concentration to efficiency. For the measurement of bank efficiency, we adopt Data Envelopment Analysis (DEA) and for the bank market concentration we use the Herfindahl-Hirschman Index (HHI). The findings confirm the relative complexity of this relationship, but they are generally in line with the structure conduct performance (SCP) paradigm and the suggestions that the increase of the banks' market power will contribute to inefficiency. Within a panel of 27 EU countries over a relatively long time period, from 1996 to the onset of the 2008 financial crisis, there is evidence that the most cost-efficient commercial and savings banks operated in less concentrated markets.
\end{abstract}

Keywords: efficiency; concentration; Granger causality; European banks 


\section{Introduction}

Economic theory generally states that in the presence of perfect imformation, market competition is associated with efficiency, while the existence of market power is synonymous with less competitiveness and inefficiency. There is also a general consensus that financial markets are characterized by the existence of asymmetric information and in order to prevent adverse selection and moral hazard, it is recommended that trust should be increased, particularly through the establishment of long-lasting relationships between the banking institutions and their clients. These lasting relationships based on trust may be associated with bank market power and may also be considered to be a necessary condition of bank efficiency. Authors like Demirgüç-Kunt and Levine (2000) suggest that the relationship between bank efficiency and bank market concentration is complex and depending on the banking market specific characteristics, this relationship may be either positive or negative.

There is a strand of literature devoted to the discussion and testing of the relationships between competitiveness and efficiency of banking markets. Most of these studies concentrate on the structural approach and mainly test the structure conduct performance (SCP) hypothesis, which considers that bank market concentration is inversely related to bank market competition (a hypothesis supported by such authors as Bikker and Haaf, 2002; Deltuvaite et al., 2007; and rejected, among others, by Classens and Laeven, 2004). Other papers analyses the reverse relationship and test the possible influence of bank efficiency on market concentration, in the context of the efficient structure hypothesis (tested, among others, by Punt and Van Rooij, 2003; Weill, 2004).

However, not many works have concentrated simultaneously on these two relationships and used Granger causality estimations to test the possible causality not only between bank concentration and efficiency, but also the reverse, i.e. between bank efficiency and market concentration (three exceptions are to be found in Schaeck and Cihak, 2008, Pruteanu-Podpiera et al., 2008, and Casu and Girardone, 2009).

This paper is a contribution to the empirical analysis of the relationship between bank efficiency and bank market concentration in the European Union. The main contributions are to be found not only in the application of a panel Granger causality approach, but also in the use of a panel of $27 \mathrm{EU}$ countries over a relatively long time period: from 1996 to 2008, taking into account that by the middle of the 1990s, Europe was preparing for the implementation of the single currency and many of the then-member states were adapting to new market conditions, whereas 2008 may be considered to mark the onset of the current financial crisis in Europe.

The findings confirm the relative complexity of the relationship between bank efficiency and market concentration, although they generally point to a negative causation running not only from efficiency to concentration, but also from concentration to efficiency.

The paper is structured as follows: Section 2 presents a brief literature review; Section 3 describes the methodological framework and the data; Section 4 reports the obtained empirical results; Section 5 summarizes and concludes. 


\section{Brief Literature Review}

The debate on the relationship between bank efficiency and market structure has its origins in the so-called "quiet life hypothesis" (Hicks, 1935), which states that the increase in market concentration is associated with fewer results, since in the absence of competition, monopoly managers do not have to fight to obtain good results.

From then on, two distinct strands in the literature reflect the views on the relationship between market consolidation and efficiency: the structural and the non-structural approaches.

The structural approach includes two competing hypotheses. On one side is the traditional structure conduct performance (SCP) hypothesis, which derives from the industrial organization literature (see among others, Bain, 1951) and considers that the level of bank market concentration is inversely related to the degree of bank competition. On the other side, we have the efficient structure hypothesis (supported by authors like Smirlock et al., 1984; Maudos, 1998), which argues that it is mainly the efficiency of the largest banks that explains the bank market consolidation.

The non-structural approach states that the bank competitive performance depends on other factors that are different from market concentration, such as the general contestability of the market, or the barriers to entry into, or exit from, the market. The non-structural approach has developed some specific models that analyse the competitive performance of the firms without using explicit information on the market structure and, in the context of the new empirical industrial organisation (NEIO) literature, include contributions of authors like Iwata (1974), Bresnaham (1982, 1989) and Panzar and Rosse (1982, 1987).

In recent years, with the global trend of bank consolidation, there has been an increase of theoretical debates and empirical analysis of the relationship between bank performance and bank market concentration.

Until the 1990s, there was a general belief that mergers did not clearly contribute to bank performance improvements and several empirical findings were consistent with the traditional SCP statements, particularly with the "quiet life hypothesis" (e.g. Berger and Hannan, 1989, 1998; Hannan and Berger, 1991; Neumark and Sharpe, 1992; Houston and Ryngaert, 1994; Pilloff, 1996).

From the year 2000, this general consensus was broken when particular attention was paid to such specific characteristics of the banking markets as the presence of asymmetric information, contagion phenomena and imperfect competition, or the specific impacts of bank concentration, competition, risk and regulation on bank performance (among others, De Bandt and Davis, 2000; Allen and Gale, 2000; Demirgüç-Kunt and Levine, 2000; Bikker and Haaf, 2002; Berger et al., 2004; Weill, 2004; Hasan et al., 2009; Schaeck et al., 2009; Tabak et al., 2011; Mahathanaseth and Tauer, 2012; Barth et al., 2013; Hall and Simper, 2013; Fiordelisi and Mare, 2013; Shin and Kim, 2013; Tang and Floros, 2013).

Furthermore, the polemic intensified with the discussion of the relationship between 


\section{Macrothink}

European bank consolidation and bank efficiency (e.g. Diaz et al., 2004; Fernandez de Guevara et al., 2005; Casu and Girardone, 2006; Fernandez de Guevara and Maudos, 2007; Altunbas and Marquês, 2007; Goddard et al., 2007; Molyneux, 2009; Fiordelisi et al., 2011).

With regard to the empirical tests of the relationship between bank efficiency (measured either by parametric methods, like the Stochastic Frontier Analysis, or by non-parametric methods, like the Data Envelopment Analysis) and bank market structure (represented by the market share or concentration indices), several papers tend to support the efficient structure hypothesis, underlining the importance of the relationship between bank cost efficiency and bank concentration or market share (see, among others, Goldberg and Rai, 1996; Berger and Hannan, 1997; Punt and Van Rooij, 2003; Weill, 2004; Maudos and Fernandez de Guevara, 2007; Williams, 2012).

However, few authors have used Granger-type causality test estimations to investigate the empirical relationship between bank efficiency and market competition.

Schaeck and Cihak (2008) analyse a large sample of EU and US banks and find evidence that competition Granger-causes profit efficiency of banks and increases profit efficiency, at least in the USA sub-sample.

Pruteanu-Podpiera et al. (2008), examining the Czech bank loan market between 1994 and 2005, reject Hick's "quiet life" hypothesis, as they find a negative relationship between competition and efficiency. Their results support the negative Granger causality, but only running from competition to efficiency and not from efficiency to competition.

Casu and Girardone (2009) apply Granger-type causality estimations to test the relationship between competition and efficiency, using bank-level balance sheet data for the commercial banks of the five largest EU countries: France, Germany, Italy, Spain and the United Kingdom, between 2000 and 2005. Once again, their findings do not support the "quiet life" hypothesis, since the Granger causality running from market power to efficiency is positive. On the other hand, there is no clear evidence that an increase in efficiency will precede any increases in a bank's market consolidation.

\section{Methodological Framework and Data}

In order to test the Granger causality relationship between bank efficiency and bank market concentration, we first present the measures chosen and data used to measure bank cost efficiency and bank market concentration, followed by the adopted Granger causality approach.

Our data are sourced from the IBCA-BankScope 2008 CD. The sample comprises annual data from consolidated accounts of the commercial and saving banks of $27 \mathrm{EU}$ countries between 1996 and 2008. Appendix 1 presents the annual number of banks for each country included in our sample. 


\subsection{Bank Efficiency}

The research into efficiency is usually based on the estimation of efficiency frontiers with the best combinations of the different inputs and outputs of the production process and then on the analysis of the deviations from the frontier that correspond to the losses of efficiency.

Most of the empirical studies on the measurement of bank efficiency adopt either parametric methods, like the Stochastic Frontier Analysis (SFA), or non-parametric methods, particularly the Data Envelopment Analysis (DEA).

Here, we adopt the DEA methodology (developed among others by Coelli et al., 1998, and Thanassoulis et al., 2007) and, using the IBCA-BankScope 2008 CD data, we will follow the intermediation approach and consider that the banks' total costs will depend on three bank outputs: total loans, total securities and other earning assets; and also of three bank inputs: borrowed funds, physical capital and labour (see Appendix 2 for a presentation of the DEA methodology and the chosen bank outputs and inputs).

Taking the available data, the DEA frontier will be defined by the piecewise linear segments that represent the combinations of the best-practice observations, the measurement of efficiency being relative to the particular frontier obtained. If the actual production of one decision-making unit (DMU) lies on the frontier, this production unit will be considered perfectly efficient, whereas if it is situated below the frontier, the DMU will be inefficient; the ratio of the actual to the potential level of production will define the level of efficiency of any individual DMU.

Thus, with the DEA approach, the efficiency score for any DMU is not defined absolutely in comparison with a universal efficiency standard; rather, it is always defined as the distance to the particular production frontier, that is, in relation to the other DMUs that are included in the specific data set. As a consequence, DEA provides efficiency scores even in the presence of relatively few observations, which represents a great advantage in comparison with the parametric approaches (like the SFA), as the latter require the availability of sufficient observations to allow the estimation of specific production functions.

Table 1 reports the obtained DEA yearly bank cost efficiency results of the EU countries for the time period between 1996 and 2008.

In spite of the year-on-year oscillations, there is a clear trend in many EU countries to the decrease of bank cost efficiency (particularly for some large countries like Germany and France, and other, smaller countries including Belgium, Denmark, Finland, Luxembourg, Sweden and the Netherlands). On the other hand, and above all in the case of some of the new EU member states, there is a trend to the increase of bank cost efficiency (particularly clear for Bulgaria, Romania and Hungary). 


\section{MlMacrothink}

Research in Applied Economics

ISSN 1948-5433

2014, Vol. 6, No. 1

Table 1. Yearly Data Envelopment Analysis (DEA) Cost Efficiency Measures

\begin{tabular}{|c|c|c|c|c|c|c|c|c|c|c|c|c|c|}
\hline & 1996 & 1997 & 1998 & 1999 & 2000 & 2001 & 2002 & 2003 & 2004 & 2005 & 2006 & 2007 & 2008 \\
\hline Austria & 0702 & 0620 & 0.595 & 0.760 & 0720 & 0.616 & 0.643 & 0.694 & 0.676 & 0.707 & 0.662 & 0.678 & 0.715 \\
\hline Belgium & 0.950 & 0.887 & 0.903 & 0.983 & 0.826 & 0.911 & 0.793 & 0.958 & 0.594 & 0.819 & 0.672 & 0.463 & 0.478 \\
\hline Bulgaria & 149 & 0.270 & 1.000 & 1.000 & .000 & 1.000 & 1.000 & 0.970 & 0.937 & 0.832 & 1.000 & 1.000 & 0.915 \\
\hline Cyprus & 1.000 & 1.000 & 1.000 & 1.000 & 1.000 & 1.000 & 0.914 & 0.725 & 0.695 & 0.679 & 0.837 & 0.800 & 0.937 \\
\hline Czech Rep. & 0.945 & 0.803 & 0.579 & 0.632 & 0.859 & 0.741 & 0.681 & 0.716 & 0.838 & 0.897 & 1.000 & 1.000 & 1.000 \\
\hline Denmark & 0.926 & 0.853 & 0.830 & 0.785 & 0.668 & 0.525 & 0.607 & 0.776 & 0.780 & 0.734 & 0.928 & 0.722 & 0.536 \\
\hline Estonia & 1.000 & 0.864 & 0.730 & 0.647 & 0.717 & 0.765 & 0.621 & 0.587 & 0.760 & 0.777 & 0.893 & 0.711 & 0.669 \\
\hline Finland & 0.783 & 1.000 & 1.000 & 1.000 & 0.737 & 1.000 & 0.687 & 0.677 & 1.000 & 0.905 & 1.000 & 0.845 & 0.579 \\
\hline France & 0.818 & 0.699 & 0.687 & 0.739 & 0.552 & 0.547 & 0.578 & 0.576 & 0.531 & 0.577 & 0.606 & 0.597 & 0.712 \\
\hline Germany & 0.948 & 0.889 & 1.000 & 0.981 & 0.772 & 0.762 & 0.887 & 0.934 & 0.956 & 0.776 & 0.821 & 0.699 & 0.606 \\
\hline Greece & 0.754 & 0.685 & 0.643 & 0.604 & 0.734 & 0.781 & 0.949 & 1.000 & 1.000 & 1.000 & 1.000 & 0.967 & 0.991 \\
\hline Hungary & 0.334 & 0.298 & 0.365 & 0.367 & 0.539 & 0.504 & 0.402 & 0.485 & 0.434 & 0.433 & 0.523 & 0.500 & 0.495 \\
\hline Ireland & 1.000 & 1.000 & 1.000 & 1.000 & 1.000 & 1.000 & 1.000 & 1.000 & 0.951 & 1.000 & 1.000 & 0.849 & 0.959 \\
\hline Italy & 1.000 & 0.872 & 1.000 & 1.000 & 0.975 & 0.802 & 0.921 & 0.924 & 1.000 & 0.958 & 0.9 & 0.741 & 0.740 \\
\hline Latvia & 1.000 & 1.000 & 0.990 & 1.000 & 1.000 & 0.947 & 0.885 & 0.910 & 0.991 & 0.827 & 0.839 & 0.721 & 0.729 \\
\hline & 1.000 & 1.000 & 1.000 & 1.000 & 1.000 & 1.000 & 1.000 & 1.000 & 1.000 & 1.000 & 1.000 & 0.900 & 0.778 \\
\hline Luxembourg & 0.879 & 0.690 & 0.730 & 0.696 & 0.654 & 0.508 & 0.564 & 0.697 & 0.673 & 0.757 & 0.523 & 0.544 & 0.524 \\
\hline Malta & 1.000 & 0.911 & 0.953 & 0.888 & 0.932 & 1.000 & 1.000 & 1.000 & 1.000 & 1.000 & 1.000 & 1.000 & 1.000 \\
\hline Netherla & 1.000 & 1.000 & 1.000 & 0.874 & 0.764 & 0.759 & 0.748 & 0.852 & 0.822 & 0.779 & 0.821 & 0.882 & 0.564 \\
\hline Poland & 0.700 & 0.591 & 0.708 & 0.596 & 0.597 & 0.604 & 0.528 & 0.593 & 0.616 & 0.605 & 0.985 & 1.000 & 0.928 \\
\hline Portugal & 0.894 & 0.808 & 0.836 & 1.000 & 0.824 & 0.638 & 0.538 & 0.438 & 0.512 & 0.562 & 0.641 & 0.599 & 0.584 \\
\hline Romania & 0.612 & 0.596 & 1.000 & 1.000 & 1.000 & 1.000 & 1.000 & 1.000 & 0.986 & 0.925 & 0.886 & 0.998 & 0.855 \\
\hline Slovakia & 1.000 & 0.823 & 0.596 & 0.613 & 0.639 & 0.658 & 0.715 & 0.753 & 0.8 & 0.8 & 0.953 & 0.902 & 1.000 \\
\hline Slovenia & 0.803 & 0.732 & 0.712 & 0.868 & 0.856 & 0.842 & 0.675 & 0.620 & 0.585 & 0.808 & 0.855 & 0.873 & 0.809 \\
\hline Spain & 1.000 & 1.000 & 1.000 & 1.000 & 1.000 & 0.997 & 1.000 & 1.000 & 1.000 & 1.000 & 1.000 & 1.000 & 1.000 \\
\hline Sweden & 0.632 & 0.675 & 0.708 & 0.724 & 0.514 & 0.638 & 0.677 & 0.695 & 0.589 & 0.626 & 0.695 & 0.509 & 0.440 \\
\hline UK & 1.000 & 1.000 & 1.000 & 1.000 & 1.000 & 1.000 & 1.000 & 1.000 & 1.000 & 1.000 & 1.000 & 1.000 & 1.000 \\
\hline
\end{tabular}

This table presents the cost efficiency results obtained with DEA, considering three outputs (total loans, total securities, and other earning assets) and three inputs (price of borrowed funds, price of physical capital and price of labor)

\subsection{Market Concentration}

Among the possible concepts and measures of market concentration, we opt to use one of the most popular: the Herfindahl-Hirschman Index (HHI) which, for each EU member-state, is calculated as the sum of the squares of all its banking institutions' market shares in terms of total assets.

For the interpretation of the HHI, we follow the general rule that considers the presence of low concentration if $\mathrm{HHI}<1000$; if $\mathrm{HHI}>1800$, there is high concentration; and if $1000<$ $\mathrm{HHI}<1800$, the market will be moderately concentrated. 
The HHI results are presented in Table 2 and clearly show that, with some exceptions, there is an increase in the bank market concentration. The exceptions are to be found in the Netherlands and Greece and most particularly in certain new EU member states, like Bulgaria, Romania and Poland, and also in the Czech Republic, Ireland, Latvia, Lithuania, Malta and Slovakia, although less strongly.

On the other hand, and in spite of the general increase in EU bank market concentration between 1996 and 2008, the levels of concentration continue to be relatively low in the five most important EU countries: France, Germany, Spain, the United Kingdom and Italy (the latter only up to 2005), countries that clearly account for the majority of the banks included in our panel.

Table 2. Yearly Market Concentration

\begin{tabular}{|c|c|c|c|c|c|c|c|c|c|c|c|c|c|}
\hline & 1996 & 1997 & 1998 & 1999 & 2000 & 2001 & 2002 & 2003 & 2004 & 2005 & 2006 & 2007 & 2008 \\
\hline Austria & 913 & 1023 & 1281 & 1564 & 1622 & 1626 & 1419 & 1229 & 941 & 1221 & 1049 & 1311 & 1084 \\
\hline Belgium & 758 & 733 & 1035 & 1659 & 1628 & 1900 & 1638 & 1336 & 1375 & 978 & 1445 & 1499 & 1499 \\
\hline Bulgaria & 2487 & 1972 & 1395 & 1394 & 1242 & 1040 & 846 & 827 & 745 & 741 & 690 & 756 & 673 \\
\hline Cyprus & 1799 & 1613 & 1560 & 1608 & 1356 & 1278 & 1315 & 1837 & 1899 & 2199 & 2719 & 2242 & 2308 \\
\hline Czech Rep. & 1182 & 1160 & 1113 & 1289 & 1366 & 1321 & 1282 & 1296 & 935 & 1015 & 1018 & 1004 & 1004 \\
\hline Denmark & 1209 & 1106 & 1106 & 1017 & 1268 & 1479 & 1519 & 1511 & 1194 & 1577 & 1542 & 1615 & 1570 \\
\hline Estonia & 1014 & 997 & 2274 & 2411 & 2516 & 2867 & 2828 & 2849 & 3720 & 4025 & 4218 & 3378 & 3378 \\
\hline Finland & 2237 & 2335 & 2375 & 2236 & 2386 & 3767 & 4311 & 2877 & 1947 & 2511 & 2758 & 2793 & 2857 \\
\hline France & 420 & 455 & 472 & 595 & 581 & 601 & 513 & 537 & 519 & 586 & 626 & 649 & 682 \\
\hline Germany & 283 & 262 & 344 & 355 & 385 & 376 & 320 & 341 & 336 & 390 & 392 & 535 & 624 \\
\hline Greece & 1099 & 981 & 914 & 792 & 896 & 899 & 869 & 856 & 485 & 870 & 812 & 853 & 845 \\
\hline Hungary & 806 & 869 & 665 & 643 & 589 & 645 & 660 & 796 & 835 & 821 & 885 & 857 & 798 \\
\hline Ireland & 1375 & 1410 & 1071 & 1171 & 1172 & 1023 & 1129 & 1081 & 815 & 886 & 963 & 1006 & 1065 \\
\hline Italy & 333 & 326 & 397 & 412 & 431 & 469 & 437 & 411 & 401 & 591 & 807 & 1051 & 1025 \\
\hline Latvia & 907 & 822 & 1028 & 932 & 847 & 865 & 828 & 744 & 660 & 716 & 750 & 697 & 735 \\
\hline Lithuania & 1368 & 1329 & 1500 & 1944 & 1823 & 1696 & 1613 & 1362 & 1265 & 1256 & 1174 & 1079 & 1057 \\
\hline Luxembourg & 301 & 299 & 333 & 330 & 346 & 371 & 398 & 392 & 366 & 381 & 365 & 276 & 318 \\
\hline Malta & 3731 & 3759 & 3699 & 4156 & 3578 & 3680 & 3706 & 2683 & 2437 & 2370 & 1938 & 2639 & 2606 \\
\hline Netherlands & 2061 & 2541 & 2647 & 2569 & 2543 & 2581 & 3232 & 2620 & 1597 & 2110 & 2418 & 1895 & 1701 \\
\hline Poland & 962 & 714 & 794 & 687 & 597 & 731 & 668 & 583 & 377 & 612 & 613 & 645 & 550 \\
\hline Portugal & 663 & 584 & 624 & 629 & 1025 & 997 & 1103 & 1158 & 1036 & $1273 i$ & 1393 & 1310 & 1327 \\
\hline Romania & 4249 & 2626 & 1733 & 1582 & 1388 & 1324 & 1254 & 1408 & 1160 & 1150 & 1102 & 1103 & 972 \\
\hline Slovakia & 2127 & 1766 & 1240 & 1486 & 1443 & 1308 & 1301 & 1330 & 1437 & 978 & 1306 & 1202 & 1253 \\
\hline Slovenia & 927 & 1032 & 1043 & 901 & 1017 & 1195 & 1218 & 1338 & 1234 & 1080 & 1130 & 1195 & 1087 \\
\hline Spain & 464 & 502 & 507 & 600 & 645 & 600 & 515 & 500 & 482 & 654 & 565 & 561 & 563 \\
\hline Sweden & 1148 & 1255 & 1243 & 1239 & 1253 & 1225 & 1298 & 1281 & 1575 & 1632 & 1598 & 1605 & 1563 \\
\hline UK & 502 & 493 & 423 & 463 & 466 & 480 & 514 & 517 & 397 & 542 & 529 & 612 & 654 \\
\hline
\end{tabular}

This table presents the obtained yearly EU countries' Herfindahl-Hirschman Index (HHI), which is the adopted market concentration measure calculated for each EU member-state as the sum of 
the squares of all the country's banking institutions' market shares, in terms of total assets.

\subsection{Panel Granger Causality Model}

We will follow the pioneer concept of Granger causality (Granger, 1969) and the approaches developed to analyse the existence of causality relationships among variables in panels (by such authors as Holtz-Eakin et al., 1988; Weinhold, 1996; Nair-Reichert and Weinhold 2001; Kónya, 2006; Hurlin and Venet, 2008), considering the general linear panel Granger causality model:

$$
y_{i, t}=\alpha+\sum_{k=1}^{K} \gamma_{i}^{(k)} y_{i, t-k}+\sum_{k=1}^{K} \beta_{i}^{(k)} x_{i, t-k}+\varepsilon_{i, t}
$$

Where: $\mathrm{y}=$ dependent variable; $\mathrm{x}=$ explanatory variable; $\mathrm{i}=1, \ldots, \mathrm{N}$ cross units; $\mathrm{t}=1, \ldots, \mathrm{T}$ time periods; $\alpha=$ intercept; $\mathrm{k}=1, \ldots \mathrm{K}$ lags; $\varepsilon=$ error term (including not only the disturbance term, but also the individual cross-unit specific effects).

To test the Granger non-causality from $\mathrm{x}$ to $\mathrm{y}$, the null hypothesis is $H_{o}: \beta_{i}=0, \forall i=1, \ldots, N$

The alternative hypothesis states that there is a causality relationship from $\mathrm{x}$ to $\mathrm{y}$ for at least one cross-unit of the panel:

$$
H_{1}: \beta_{i}=0, \forall i=1, \ldots, N_{1} ; \beta_{i} \neq 0, \forall i=N_{1}+1, N_{1}+2 \ldots, N ;\left(0 \leq \frac{N_{1}}{N} \leq 1\right)
$$

Before proceeding with the panel Granger causality estimations, we test the stationarity of the series, using two panel unit root tests: the Levin, Lin and Chu (2002) and the Im, Pesaran and Shin (2003).

The Levin, Lin and Chu (2002) may be viewed as a pooled Dickey-Fuller test, or as an augmented Dickey-Fuller test, when lags are included and the null hypothesis is the existence of non-stationarity. This test is adequate for heterogeneous panels of moderate size, like the panels used in this paper, and it assumes that there is a common unit root process. The results reported in Table 3-A clearly allow us to reject the existence of the null hypothesis.

The Im, Pesaran and Shin (2003) test estimates the t-test for unit roots in heterogeneous panels and allows for individual unit root processes. It is based on the mean of the individual Dickey-Fuller t-statistics of each unit in the panel and assumes that all series are non-stationary under the null hypothesis. Table 3-B presents the results obtained with this test, which confirm the rejection of the non-stationarity.

Table 3. Panel Unit Root Tests

\begin{tabular}{ccccc}
\multicolumn{4}{c}{ Table 3-A - Levin, Lin and Chu (2002) (LEVINLIN) tests } \\
\hline Variables & coefficient & t-star & P > t & obs. \\
\hline Cost efficiency. (DEA) & -0.43473 & -4.25875 & 0.0000 & 312 \\
Herfindahl-Hirschman Index & -0.28545 & -6.12162 & 0.0000 & 312 \\
\hline
\end{tabular}




\begin{tabular}{ccccc}
\multicolumn{5}{c}{ Table 3-B - Im, Pesaran and Shin (2003) (IPSHIN) tests } \\
\hline Variables & t-bar & W[t-bar] & P-value & obs. \\
\hline Cost efficiency. (DEA) & -1.819 & -1.618 & 0.053 & 312 \\
Herfindahl-Hirschman Index & -1.815 & -1.600 & 0.055 & 312 \\
\hline
\end{tabular}

This table presents the results obtained with the statistical software Stata, for two specific panel unit root tests that are recommended for heterogeneous panels of moderate size.

\section{Results}

In our panel Granger-type causality test estimations, we will first use panel ordinary least squares (OLS) estimations and fixed-effects panel estimations (following among others Wooldridge, 2002; Baltagi, 2008).

To test the panel dynamics of the model, we will also use Generalised Method of Moments (GMM) one-step "difference" and two-step "system" estimations, following the contributions of Holtz-Eakin et al. (1988), Arellano and Bond (1991), Blunder and Bond (1998) and Windmeijer (2005).

\subsection{Results Obtained with Panel OLS and Fixed-Effects Estimations}

Table 4 reports the obtained results with panel ordinary least squares (OLS) robust estimations and panel fixed-effects robust estimations, both for the causality running from bank market concentration to bank efficiency (Table 4A ) and for the causality running from efficiency to concentration (Table 4B).

In both situations, the obtained $\mathrm{F}$ statistics and R-squared values allow us to conclude that the results are statistically significant. A more careful observation of the R-squared values obtained with fixed-effects estimations reveals the relative cross-section homogeneity of the panel, since the cross-section evolution (represented by the R-squared "between") is in both cases more important than the time evolution (represented by the R-squared "within").

In addition, the results reported in Table 4 show that both DEA bank cost efficiency and bank market concentration clearly depend on their own past levels, with a positive signal associated to the first lags and a negative signal associated to the second lags.

In Table 4A, it is also clear that the bank concentration of the previous year (first lag) has a negative and statistically significant influence on bank cost efficiency, while the influence of the second lag is less statistically significant. Moreover, the obtained causality Granger coefficients, although not very high, are negative, revealing that an increase in bank concentration is associated to less bank efficiency.

With reference to the causality running from DEA cost efficiency to bank concentration (Table 4B), the results obtained are statistically stronger than those obtained for the causality running from concentration to efficiency. There is now a negative influence, both of the first and second lags of bank efficiency on bank concentration. The importance of this influence is reinforced by the relatively high and in negative values of the Granger coefficients, which 
seems to indicate that the most efficient banks are those that are obliged to compete in less concentrated markets.

Table 4. OLS Robust and Fixed-Effects Robust Panel Estimations

Table 4 - A - Dependent variable: Cost Efficiency (DEA); explanatory variable: Herfindahl-Hirschman Index (HHI)

\begin{tabular}{|c|c|c|c|c|c|c|}
\hline & \multicolumn{3}{|c|}{ OLS robust } & \multicolumn{3}{|c|}{ Fixed-effects robust } \\
\hline & coef. & $\mathrm{t}$ & $\mathrm{P}>|\mathrm{t}|$ & coef. & $\mathrm{t}$ & P-value \\
\hline Cost Efficiency (DEA) t-1 & .5275357 & 7.91 & 0.000 & .5066752 & 7.10 & 0.000 \\
\hline Cost Efficiency (DEA) t-2 & -.1211041 & -1.64 & 0.101 & -.1167477 & -1.61 & 0.108 \\
\hline Herfindahl-Hirschman Index(HHI) t-1 & -.0669345 & -1.88 & 0.061 & -.0709854 & -1.79 & 0.074 \\
\hline \multirow{5}{*}{$\begin{array}{r}\text { Herfindahl-Hirschman Index (HHI) t-2 } \\
\text { constant }\end{array}$} & .0282319 & 1.19 & 0.236 & .0230154 & 0.83 & 0.409 \\
\hline & .1089059 & 0.43 & 0.669 & .1875666 & 0.66 & 0.510 \\
\hline & \multicolumn{2}{|c|}{ R-squared: $=0.6552$} & & R-squared: & $\begin{array}{l}\text { within } \\
\text { between } \\
\text { overall }=\end{array}$ & \\
\hline & \multicolumn{3}{|c|}{$F(42,306)=31.45$} & \multicolumn{3}{|c|}{$\mathrm{F}$ test $=15.24$} \\
\hline & & (Prob. $>\mathrm{F}=$ & $0.0000)$ & \multicolumn{3}{|c|}{$($ Prob. $>F=0.0000)$} \\
\hline Number of observations & & 349 & & \multicolumn{3}{|c|}{349} \\
\hline GRANGER COEFFICIENT & & -0.0387 & & \multicolumn{3}{|c|}{-0.04797} \\
\hline
\end{tabular}

Table 4 - B - Dependent variable: Herfindahl-Hirschman Index (HHI); explanatory variable: Cost Efficiency (DEA)

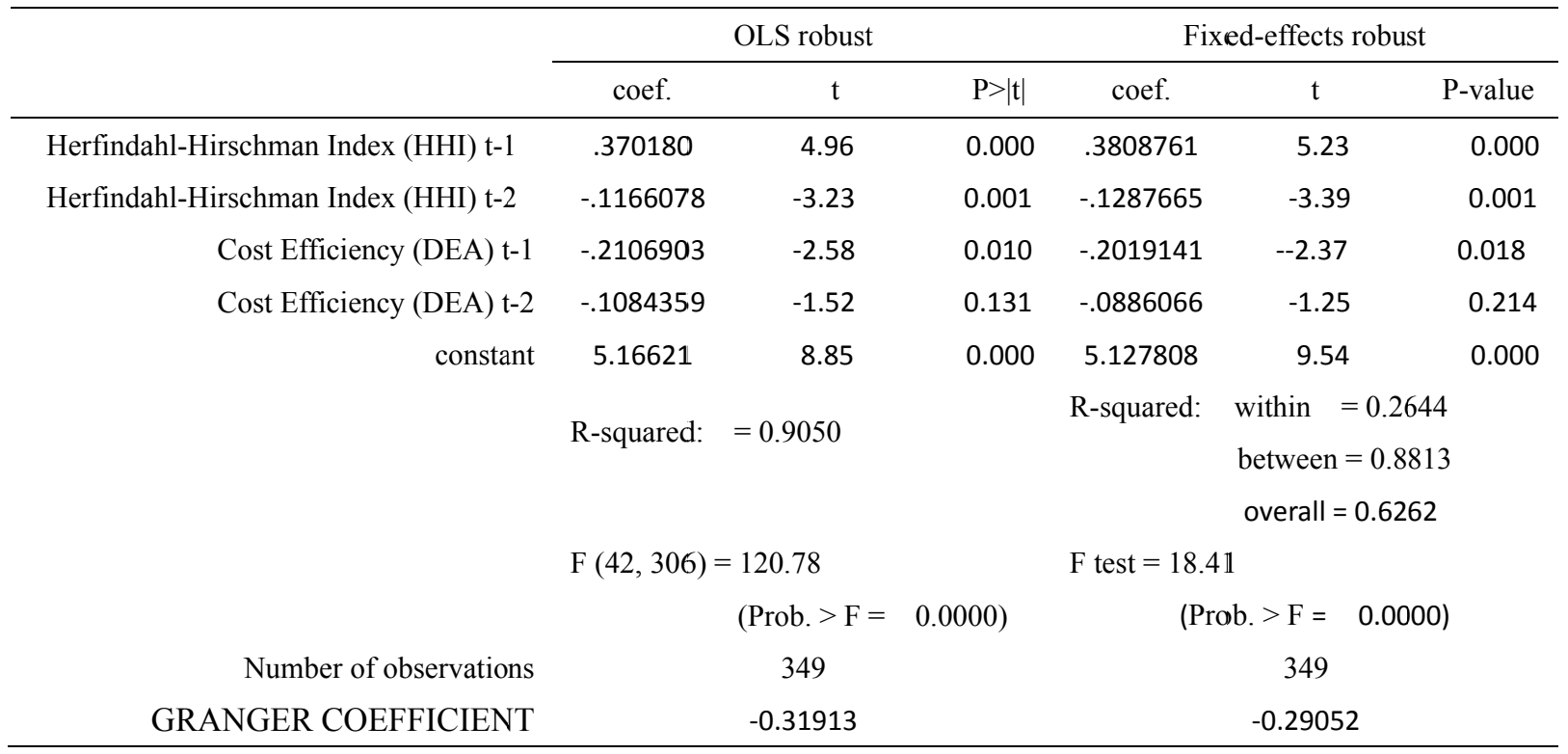

This table presents the obtained results for equation (1) with pooled OLS robust and fixed-effects robust panel estimations. 
4.2 Results Obtained with GMM One-Step "Difference" and Two-Step "System" Estimations

In order to test the robustness of the previous results and the panel dynamics of the model, we also apply Generalized Method of Moments (GMM) one-step "difference" and two-step "system" robust estimations. The results obtained are presented in Table 5.

With regard to the causality running from bank market concentration to bank cost efficiency, the results, presented in Table 5A, although statistically less strong than those reported in Table 4A, reveal that in spite of the oscillations in the signs of the considered two lags, the joint-influence represented by the Granger coefficients is also always negative and it is relatively high for the two-step "system" robust estimations.

In contrast, for the causality running from efficiency to concentration, the results, reported in Table 5B, are not only statistically less robust, again presenting some oscillations in the lags' signals, but also they are not in line with the previous results. Now the Granger coefficients are always positive, revealing that an increase in efficiency could be associated to the consolidation of the banking institutions' market power.

Table 5. Dynamic Arellano-Bond One-Step and Two-Step Difference Robust GMM Estimations

Table 5 - A: Dependent variable: Cost Efficiency (DEA); explanatory variable: Herfindahl-Hirschman Index (HHI)

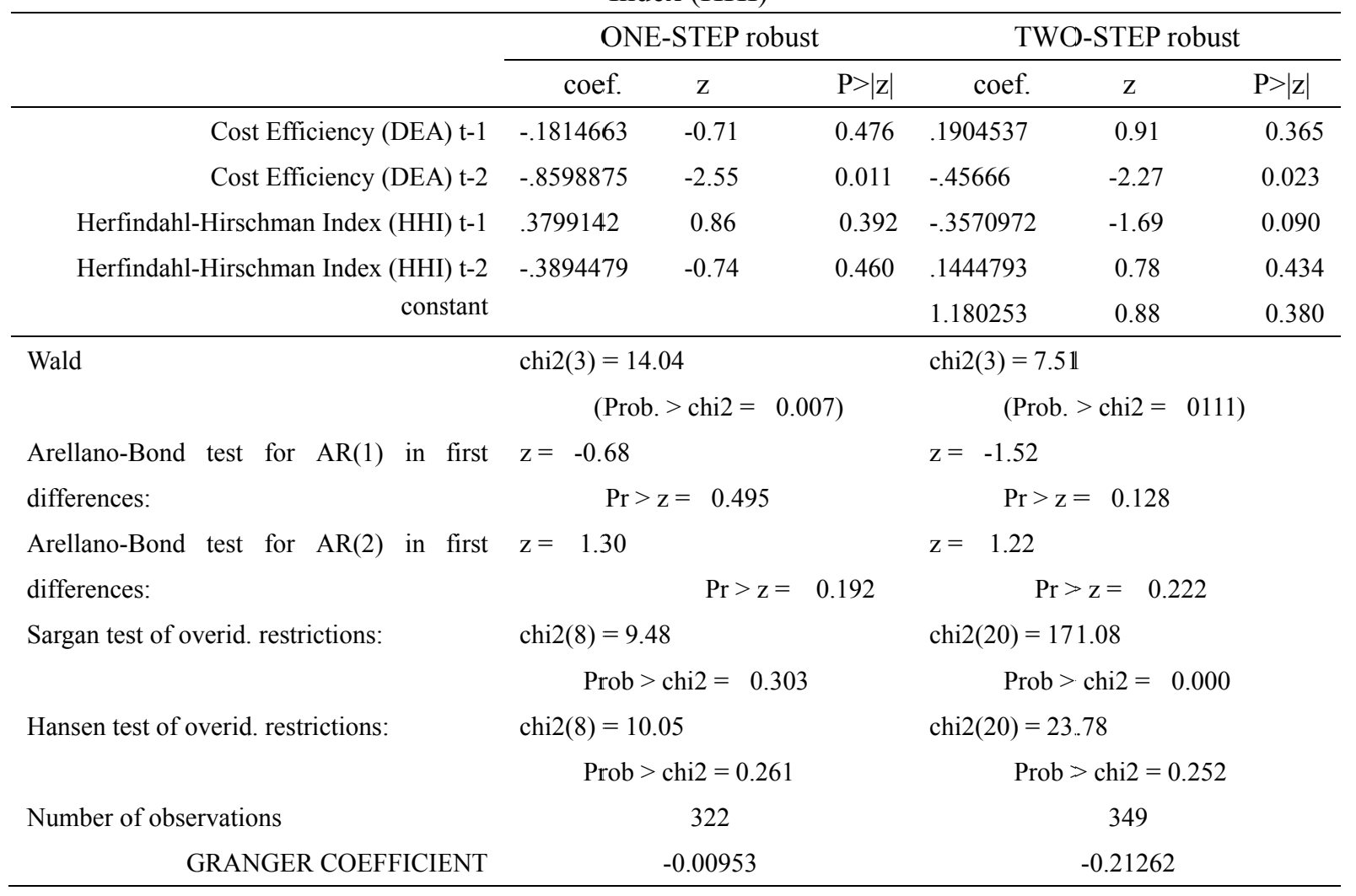


Table 5 - B: Dependent variable: Herfindahl-Hirschman Index (HHI); explanatory variable: Cost Efficiency (DEA)

\begin{tabular}{|c|c|c|c|c|c|c|}
\hline & \multicolumn{3}{|c|}{ ONE-STEP robust } & \multicolumn{3}{|c|}{ TWO-STEP robust } \\
\hline & coef. & $\mathrm{z}$ & $\mathrm{P}>|\mathrm{z}|$ & coef. & $\mathrm{z}$ & $\mathrm{P}>|\mathrm{z}|$ \\
\hline Herfindahl-Hirschman Index (HHI) t-1 & .2324312 & 0.89 & 0.374 & .5899106 & 3.88 & 0.000 \\
\hline Herfindahl-Hirschman Index (HHI) t-2 & -.4062913 & -1.23 & 0.220 & -.215635 & -0.75 & 0.443 \\
\hline Cost Efficiency (DEA) t-1 & -.0262511 & -0.05 & 0.959 & -.2495609 & -0.75 & 0.455 \\
\hline \multirow{2}{*}{$\begin{array}{r}\text { Cost Efficiency (DEA) t-2 } \\
\text { constant }\end{array}$} & .6675242 & 1.53 & 0.126 & .3697278 & 1.54 & 0.123 \\
\hline & & & & 4.3776 & 2.96 & 0.003 \\
\hline \multirow[t]{2}{*}{ Wald } & \multicolumn{3}{|c|}{$\operatorname{chi} 2(3)=10.33$} & \multicolumn{3}{|c|}{$\operatorname{chi} 2(3)=31.47$} \\
\hline & \multicolumn{3}{|c|}{$($ Prob. $>$ chi $2=0.035)$} & \multicolumn{3}{|c|}{$($ Prob. $>$ chi $2=0.000)$} \\
\hline \multirow{2}{*}{$\begin{array}{l}\text { Arellano-Bond test for } \mathrm{AR}(1) \text { in first } \\
\text { differences: }\end{array}$} & \multicolumn{3}{|l|}{$z=-1.78$} & \multicolumn{3}{|l|}{$z=-1.49$} \\
\hline & \multicolumn{3}{|c|}{$\operatorname{Pr}>z=0.074$} & \multicolumn{3}{|c|}{$\operatorname{Pr}>z=0.137$} \\
\hline \multirow{2}{*}{$\begin{array}{l}\text { Arellano-Bond test for } \mathrm{AR}(2) \text { in first } \\
\text { differences: }\end{array}$} & \multicolumn{3}{|l|}{$\mathrm{z}=1.17$} & \multicolumn{3}{|l|}{$z=0.64$} \\
\hline & & $\operatorname{Pr}>z=$ & 0.240 & & $>z=0$ & 520 \\
\hline \multirow[t]{2}{*}{ Sargan test of overid. restrictions: } & \multicolumn{3}{|c|}{$\operatorname{chi} 2(8)=12.16$} & \multicolumn{3}{|c|}{$\operatorname{chi} 2(20)=139.55$} \\
\hline & Prob & $>\operatorname{chi} 2=$ & 0.144 & Prol & $\operatorname{chi} 2=$ & 0.000 \\
\hline \multirow[t]{2}{*}{ Hansen test of overid. restrictions: } & \multicolumn{3}{|c|}{$\operatorname{chi} 2(8)=14.36$} & \multicolumn{3}{|c|}{$\operatorname{chi} 2(20)=23.17$} \\
\hline & \multicolumn{3}{|c|}{ Prob $>$ chi $2=0.073$} & \multicolumn{3}{|c|}{ Prob $>$ chi $2=0.281$} \\
\hline Number of observations & \multicolumn{3}{|c|}{322} & \multicolumn{3}{|c|}{349} \\
\hline GRANGER COEFFICIENT & \multicolumn{3}{|c|}{0.641273} & \multicolumn{3}{|c|}{0.120167} \\
\hline
\end{tabular}

This table presents the obtained results for equation (1) with Generalised Method of Moments (GMM) one-step "difference" and two-step "system" robust estimations.

In order to analyse the robustness of these results obtained with GMM panel estimations and to compare them with the results previously obtained with panel OLS and fixed-effects estimations, we apply F (and Wald) tests, supposing in all situations the joint-hypothesis $\beta_{1}=$ $\beta_{2}=0$. The results obtained are reported in Table 6 , which also summarizes the values of the Granger coefficients.

The first line of Table 6 reveals the results for causality running from market concentration to bank efficiency, allowing us to conclude that there is a clear negative relationship, which means that in all situations, the increase of market consolidation will contribute to less bank efficiency.

However, regarding the causality running from bank efficiency to market concentration, the results presented in the second line of Table 6 are contradictory: using OLS and fixed-effects estimations, we obtain a negative influence, but a positive influence is obtained if we apply dynamic GMM estimations. The comparison of the $\mathrm{F}$ and Wald tests results allows us to confirm that with our panel, OLS and fixed-effects results are a little more robust and can validate the negative causality running from bank cost efficiency to bank market concentration. 
Table 6. Granger Coefficients and F (Wald) Tests

\begin{tabular}{|c|c|c|c|c|}
\hline & OLS robust & Fixed effects robust & ONE-STEP robust & TWO-STEP robust \\
\hline $\begin{array}{l}\text { A- Dep. var: Cost } \\
\text { Efficiency } \quad \text { (DEA); } \\
\text { expl.var: }\end{array}$ & -0.0387 & -0.04797 & -0.00953 & -0.21262 \\
\hline Herfindahl-Hirschman & $F(2,306)=2.00$ & $F(2, \quad 318)=1.66$ & $\operatorname{chi} 2(2)=4.18$ & $\operatorname{chi} 2(2)=2.88$ \\
\hline Index (HHI) & Prob $>F=0.1367$ & Prob $>F=0.1916$ & Prob $>$ chi $2=0.1239$ & Prob $>$ chi $2=0.2364$ \\
\hline Dep & & & & \\
\hline $\begin{array}{l}\text { Herfindahl-Hirschman } \\
\text { Index (HHI); }\end{array}$ & -0.31913 & -0.29052 & 0.641273 & 0.120167 \\
\hline expl var: & $F(2,306)=6.25$ & $\mathrm{~F}(2,318)=5.33$ & $\operatorname{chi} 2(2)=5.11$ & $\operatorname{chi} 2(2)=2.48$ \\
\hline Efficiency (DEA) & Prob $>F=0.0022$ & Prob $>F=0.0053$ & Prob $>$ chi $2=0.0779$ & Prob $>$ chi $2=0.2894$ \\
\hline
\end{tabular}

This table presents the Granger coefficients (that is the sum of the estimated $\beta$ s from equation (1) and the $F$ or Wald tests results that were obtained for equation (1) with OLS, panel fixed effects, GMM one-step "difference" and GMM two-step "system" robust estimations.

\section{Summary and Conclusions}

This paper aims to provide new empirical evidence on the rather controversial relationship between bank market concentration and bank efficiency. The main contributions are to be found in the application of a panel Granger causality approach, using annual data from the consolidated accounts of the commercial and savings banks of 27 European Union countries collected from the IBCA-BankScope 2008 CD for the time period 1996-2008.

For bank market concentration, we opt to use a popular measure: the Herfindahl-Hirschman Index (HHI), calculated for each EU country as the sum of the squares of all the country's commercial and savings banking institutions' market shares. The results obtained reveal that with some exceptions, there is a general trend to the increase of EU bank market concentration during the considered period. However, for the largest EU countries (France, Germany, Spain, the United Kingdom and Italy), the levels of concentration remain relatively low.

To measure bank cost efficiency, we use the DEA non-parametric estimations, following the intermediation approach and considering three bank outputs: total loans, total securities and other earning assets; and three bank inputs: the price of the borrowed funds, the price of capital and the price of labor. The results show that in spite of some year-on-year oscillations and the specific cases of some EU member states, the general trend is for the bank cost efficiency to decrease, a trend that is particularly evident in the last years of the considered period.

In order to test statistically the panel Granger causality between EU bank market concentration and the cost efficiency of the EU banks, we consider models with two lags both 
of the dependent and independent variables and use different panel robust estimation techniques: OLS, fixed effects, GMM one-step "difference" and GMM two-step "system".

The results obtained with these techniques confirm the complexity of the relationships between bank market concentration and bank cost efficiency in the panel of the $27 \mathrm{EU}$ countries. Similarly to the Granger causality results obtained by, for example, Casu and Girardone (2009), there are not only clear oscillations in the influences of the first and second lags of the variables, but specifically for the causality running from bank efficiency to market concentration, there are also some contradictions in the results obtained with different estimation techniques.

However, a careful comparison of the obtained Granger coefficients and the values provided by the $\mathrm{F}$ and Wald tests allows us to conclude that the causality running from concentration to efficiency is clearly negative. These results are in line with the SCP paradigm, as well as the suggestions that the banks acting in more concentrated markets will contribute to inefficiency as a result of their lesser efforts to acquire more outputs with less costs (Berger and Hannan, 1998; Bikker and Haaf, 2002; Schaeck and Cihak, 2008; Chortareas et al., 2011).

In addition, with regard to the causality running from bank cost efficiency to bank market concentration, the obtained Granger coefficients and the values of the F and Wald tests also provide evidence of the importance of this relationship. Nonetheless, the obtained results do not allow us to validate the efficient structure hypothesis. They are more in line with the arguments in favour of the possibility of the smaller banks being more effective than the larger banks (Goddard et al., 2001), or those findings that suggest that even when larger banks have higher performance, this advantage decreases in concentrated markets (Tabak et al., 2011). To summarise, our results suggest that in the panel comprising all 27 European Union countries, between 1996 and 2008, the most cost-efficient banks operated in less concentrated markets.

\section{Acknowledgement}

Financial support from national funds by FCT (Fundação para a Ciência e a Tecnologia). This article is part of the Strategic Project:_PEst-OE/EGE/UI0436/2011

We thank the participants at the $7^{\text {th }}$ Conference of the Portuguese Finance Network, Aveiro, Portugal, July, 2012 for their helpful comments, critics and suggestions. Thanks are also particularly due to the anonymous referee(s) for their pertinent report. The usual disclaimer remains 


\section{References}

Allen, F., \& Gale, D. (2000). Financial Contagion. Journal of Political Economy, 108, 1-33.

Altunbas, Y., \& Marquês, D. (2007). Mergers and acquisitions and bank performance in Europe. The role of strategic similarities. Journal of Economics and Business, 60, 204-222.

Arellano, M., \& Bond, S.R. (1991). Some Tests of Specification for Panel Data: Monte Carlo Evidence and An Application to Employment Equations. Review of Economic Studies, $58,277-297$.

Bain, J.S. (1951). Relation of Profit Rate to Industry Concentration. Quarterly Journal of Economics, 65, 293-324.

Baltagi, H. B. (2008). Econometric Analysis of Panel Data(Forth Edition.). John Wiley \& Sons Ltd.

Banker, R. D., Charnes, A., \& Cooper, W. W. (1984). Some models for the estimating technical and scale inefficiency in Data Envelopment Analysis. Management Science, 30, 1078-1092.

Barth, J. R., Lin, C., Ma, Y., Seade, J., \& Song, F.M. (2013). Do bank regulation, supervision and monitoring enhance or impede bank efficiency?. Journal of Banking and Finance, $37,2879-2892$.

Berger, A.N., Demirgüç-Kunt, A., Levine R., \& Haubrich, J. G. (2004). Bank Concentration and Competition: An Evolution in the Making. Journal of Money, Credit and Banking, 36, 433-453. http://dx.doi.org/10.1353/mcb.2004.0040

Berger, A. N., \& Hannan, T. H. (1989). The Price-Concentration Relationship in Banking. Review of Economics and Statistics, 71, 291-299.

Berger, A., \& Hannan, T. H. (1997). Using Efficiency Measures to Distinguish among Alternative Explanations of the Structure-Performance Relationship in Banking. Managerial Finance, 1, 6-31.

Berger, A. N., \& Hannan, T. H. (1998). The Efficiency Cost of Market Power in the Banking Industry: A Test of the 'Quiet Life' and Related Hypotheses. Review of Economics and Statistics, 80, 454-465.

Bikker, J., \& Haaf, K. (2002). Competition, concentration and their relationship: An empirical analysis of the banking industry. Journal of Banking and Finance, 26, 2191-2214.

Blundell, R., \& Bond, S.R. (1998). Initial Conditions and Moment Restrictions in Dynamic Panel Data Models. Journal of Econometrics, 87, 115-43.

Bresnahan, T. F. (1982). The Oligopoly Solution Concept is Identified. Economics Letters, 10, 87-92.

Bresnahan, T. F. (1989). Empirical Studies of Industries with Market Power. In: Schmalensee, 
R., \& Willig, R. D. (Eds.), Handbook of Industrial Organisation, vol. II. Elsevier, Amsterdam, 1012-1055.

Casu, B., \& Girardone, C. (2006). Bank Competition, Concentration and Efficiency in the Single European Market. The Manchester School, 74, 441-468.

Casu, B., \& Girardone, C. (2009). Does Competition Lead to Efficiency? The Case of EU Commercial Banks, Cass Business School, Working Paper Series, WP 01/09. Available at SSRN: http://ssrn.com/abstract=1200362 or http://dx.doi.org/10.2139/ssrn.1200362

Charnes A., Cooper, W.W., \& Rhodes, E. (1978). Measuring the Efficiency of Decision-Making Units. European Journal of Operational Research, 2, 429 - 444.

Chortareas, G.E., Garza-Garcia, J. G., \& Girardone, C. (2011). Banking Sector Performance in some Latin American Countries: Market Power versus Efficiency. Review of Development Economics, 15, 307-325.

Claessens, S., \& Laeven, L. (2004). What drives bank competition? Some international evidence. Journal of Money, Credit, and Banking, 36, 563-583.

Coelli, T.J., Prasada Rao, D. S., \& Battese, G. (1998). An Introduction to Efficiency and Productivity Analysis. Norwell, Kluwer Academic Publishers.

De Bandt, O., \& Davis, E.P. (2000). Competition, Contestability and Market Structure in European Banking Sectors on the Eve of EMU. Journal of Banking and Finance, 24, 1045-1066.

Deltuvaite, V., Vaskelaitis, V., \& Pranckeviciute, A. (2007). The impact of concentration on competition and efficiency in the Lithuanian banking sector. Economics of Engineering Decisions, 54, 7-19

Demirgüç-Kunt A., \& Levine, R. (2000). Bank Concentration: Cross-Country Evidence. World Bank, mimeo, Retrieved from http://www-wds.worldbank.org/external/default/WDSContentServer/WDSP/IB/2004/02/ 10/000265513_20040210165243/additional/310436360_20050276035212.pdf

Diaz, B. D., Olalla, M. G., \& Azofra, S. S. (2004). Bank acquisitions and performance: evidence from a panel of European credit entities. Journal of Economics and Business, $56,377-404$.

Fernandez de Guevara, J., Maudos, J., \& Perez, F. (2005). Market power in the European banking sector. Journal of Financial Services Research, 27, 109-137.

Fernandez de Guevara, J., \& Maudos, J. (2007). Explanatory factors of market power in the banking system. Manchester School, 75, 275-296.

Fiordelisi, F., \& Mare, D.S. (2013). Probability of default and efficiency in cooperative banking. Journal of International Financial Markets, Institutions and Money, 26, 30-45. http://dx.doi.org/10.1016/j.intfin.2013.03.003 
Fiordelisi, F., Marques-Ibanez, D., \& Molyneux, P. (2011). Efficiency and risk in European banking. Journal of Banking and Finance, 35, 1315-1326.

Goddard, J., Molyneux, P., \& Wilson, J. (2001). European Banking, Efficiency, Technology and Growth. John Wiley and Sons, England.

Goddard, J.A., Molyneux, P., \& Wilson, J. O. S. (2007). European banking: an overview. Journal of Banking and Finance, 31, 1911-1935.

Goldberg, L., \& Rai, A. (1996). The Structure-Performance Relationship in European Banking. Journal of Banking and Finance, 20, 745-771.

Granger, C. W.J. (1969). Investigating Causal Relations by Econometric Models and Cross-Spectral Methods. Econometrica, 37,424-438.

Hall, M. J. B., \& Simper, R. (2013). Efficiency and competition in Korean banking. Applied Financial Economics, 23, 881-890. http://dx.doi.org/10.1080/09603107.2013.776661

Hannan, T. H., \& Berger, A. N. (1991). The Rigidity of Prices: Evidence from the Banking Industry. American Economic Review, 81, 938-945.

Hasan, I., Koetter, M., \& Wedow, M. (2009). Regional growth and finance in Europe: Is there a quality effect of bank efficiency?. Journal of Banking and Finance, 33, 1446-1453.

Hicks, J. (1935). The Theory of Monopoly. Econometrica, 3, 1-20.

Holtz-Eakin, D., Newey, W., \& Rosen, H.S. (1988). Estimating Vector Autoregressions with Panel Data. Econometrica, 56, 1371-95.

Houston, J. F., \& Ryngaert, M. (1994). The overall gains from large bank mergers. Journal of Banking and Finance, 18, 55-1176.

Hurlin, C., \& Venet, B. (2008). Financial Development and Growth: A Re-Examination using a Panel Granger Causality Test” Working Paper halshs-00319995, version 1.

Im, K., Pesaran, M., \& Shin, Y. (2003). Testing for Unit Roots In Heterogeneous Panels. Journal of Econometrics, 115, 53-74.

Iwata G. (1974). Measurement of Conjectural Variations in Oligopoly. Econometrica, 42, 947-966.

Kónya, L. (2006). Exports \& growth: Granger causality analysis on OECD countries with a panel data approach. Economic Modelling, 23, 978-992.

Levin, A, Lin, C., \& Chu, C. (2002). Unit Root Tests in Panel Data: Asymptotic and Finite Sample Properties. Journal of Econometrics, 108, 1-24.

Mahathanaseth, I., \& Tauer, L. W. (2012). Market-power versus cost-efficiency in Thailand's banking sector in the post-crisis period (1998-2011). Journal of Asian Economics, 23, 499-506.

Maudos, J. (1998). Market structure and performance in Spanish banking using a direct 
measure of efficiency. Applied Financial Economics, 8, 191-200.

Maudos, J., \& Fernandez de Guevara, J. (2007). The Cost of Market Power in Banking: Social Welfare Loss vs. Cost Inefficiency. Journal of Banking and Finance, 31, 2103 -2125 .

Molyneux, P. (2009). Do Mergers Improve Bank Productivity and Performance? in Productivity in the Financial Services, Edited by Balling, M., Gnan, E., Lierman, F. \& Schoder, J.-P. , SUERF Studies, Vienna, 23-43.

Nair-Reichert, U., \& Weinhold, D. (2001). Causality tests for cross-country panels: a look at FDI and economic growth in less developed countries. Oxford Bulletin of Economics and Statistics, 63, 153-171.

Neumark, D., \& Sharpe, S. A. (1992). Market Structure and the Nature of Price Rigidity: Evidence from the Market for Consumer Deposits. Quarterly Journal of Economics, 107, $657-80$.

Panzar, J. C., \& Rosse, J. N. (1982). Structure, conduct and comparative statistics, Bell Laboratories Economic Discussion Paper.

Panzar, J. C., \& Rosse, J. N. (1987). Testing for 'monopoly' equilibrium. Journal of Industrial Economics, 35, 443-456.

Pilloff, S. J. (1996). Performance changes and shareholder wealth creation associated with mergers of publicly traded banking institutions. Journal of Money, Credit and Banking, 28, 294-310.

Pruteanu-Podpiera, A., Weill, L., \& Schobert, F. (2008). Banking Competition and Efficiency: a Micro-Data Analysis on the Czech Banking Industry. Comparative Economic Studies, 50, 253-273.

Punt, L., \& Van Rooij, M. (2003). The Profit-Structure Relationship and Mergers in the European Banking Industry: An Empirical Assessment. Kredit und Kapital, 36, 1-29.

Schaeck, K., \& Cihak, M. (2008). How does competition affect efficiency and soundness in banking? New empirical evidence, ECB Working Paper Series, N. 932.

Shaeck, K., Cihak, M. \& Wolfe, S. (2009). Are more competitive banking systems more stable?. Journal of Money, Credit and Banking, 41, 711-734. http://dx.doi.org/10.1111/j.1538-4616.2009.00228

Shin, D.J., \& Kim, B.H.S. (2013). Bank consolidation and competitiveness: empirical evidence from the Korean banking industry. Journal of Asian Economics, 24, 41-50.

Smirlock, M., Gilligan, T., \& Marshall,W. (1984). Tobin's q and the Structure-Performance Relationship. American Economic Review, 74, 1050-60.

Tabak, B. M., Dimas, D. M., \& Cajueiro, D. O. (2011). Profit, Cost and Scale Efficiency for Latin American Banks: concentration-performance relationship, Banco Central do 
Brasil, Working Paper Series N. 244.

Tang, Y., \& Floros, C. (2013). Risk, capital and efficiency in Chinese banking. Journal of International Financial Markets, Institutions and Money, 26, 378-393.

Thanassoulis, E. (2001). Introduction to the Theory and Application of Data Envelopment Analysis. A Foundation Text with Integrated Software, USA, Kluwer Academic Publishers.

Thanassoulis, E., Portela, M.C.S., \& Despic, O. (2007). DEA - The Mathematical Programming Approach to Efficiency Analysis" in The Measurement of Productive Efficiency and Productivity Growth. 2007, in Fried, H. O., Lovell, C. A. K. \& Schmidt, S.S. (editors), Oxford University Press.

Weill L. (2004). On the Relationship between Competition and Efficiency in the EU Banking Sector. Kredit und Kapital, 37, 29-352.

Weinhold, D. (1996). Testes de causalité sur donnés de panel: une application à l'étude de la causalité entre l'investissement et la croissance. Économie et prévision, 126, 163-175.

Williams, J. (2012). Efficiency and market power in Latin American banking. Journal of Financial Stability, 8, 263-276.

Windmeijer, F. (2005). A Finite Sample Correction for the Variance of Linear Efficient Two-Step GMM Estimators. Journal of Econometrics, 126, 25-51.

Wooldridge, J. (2002). Econometric Analysis of Cross Section and Panel Data. The MIT Press. 
Appendix 1. Yearly number of banks by EU country

\begin{tabular}{|c|c|c|c|c|c|c|c|c|c|c|c|c|c|}
\hline & 1996 & 1997 & 1998 & 1999 & 2000 & 2001 & 2002 & 2003 & 2004 & 2005 & 2006 & 2007 & 2008 \\
\hline Austria & 72 & 122 & 124 & 124 & 129 & 140 & 142 & 146 & 154 & 153 & 162 & 162 & 147 \\
\hline Belgium & 97 & 91 & 75 & 73 & 68 & 69 & 72 & 73 & 72 & 71 & 58 & 47 & 34 \\
\hline Bulgaria & 16 & 19 & 22 & 21 & 25 & 27 & 28 & 29 & 30 & 30 & 29 & 22 & 21 \\
\hline Cyprus & 17 & 23 & 25 & 21 & 23 & 23 & 24 & 18 & 17 & 16 & 11 & 11 & 9 \\
\hline Czech Rep. & 28 & 28 & 25 & 25 & 27 & 28 & 27 & 26 & 31 & 27 & 25 & 25 & 20 \\
\hline Denmark & 113 & 113 & 117 & 118 & 123 & 116 & 113 & 112 & 129 & 120 & 123 & 121 & 109 \\
\hline Estonia & 16 & 18 & 8 & 8 & 10 & 10 & 11 & 11 & 12 & 11 & 11 & 12 & 10 \\
\hline Finland & 11 & 12 & 12 & 12 & 14 & 13 & 12 & 14 & 19 & 16 & 11 & 11 & 12 \\
\hline France & 345 & 323 & 312 & 306 & 308 & 305 & 295 & 283 & 292 & 283 & 256 & 237 & 204 \\
\hline Germany & 827 & 830 & 818 & 791 & 771 & 737 & 708 & 682 & 675 & 677 & 685 & 675 & 593 \\
\hline Greece & 29 & 35 & 33 & 30 & 26 & 26 & 31 & 34 & 55 & 35 & 33 & 30 & 29 \\
\hline Hungary & 34 & 33 & 34 & 37 & 39 & 35 & 37 & 33 & 33 & 36 & 35 & 31 & 26 \\
\hline Ireland & 34 & 36 & 40 & 40 & 42 & 44 & 46 & 47 & 63 & 51 & 50 & 47 & 40 \\
\hline Italy & 200 & 219 & 219 & 228 & 216 & 229 & 232 & 240 & 363 & 304 & 226 & 222 & 199 \\
\hline Latvia & 21 & 25 & 24 & 24 & 25 & 26 & 27 & 30 & 33 & 36 & 36 & 36 & 33 \\
\hline Lithuania & 11 & 13 & 13 & 14 & 16 & 16 & 16 & 17 & 17 & 17 & 18 & 18 & 15 \\
\hline Luxembourg & 122 & 123 & 117 & 123 & 112 & 100 & 96 & 92 & 93 & 91 & 92 & 105 & 80 \\
\hline Malta & 9 & 9 & 10 & 8 & 10 & 9 & 9 & 14 & 16 & 17 & 18 & 17 & 14 \\
\hline Netherlands & 64 & 58 & 57 & 55 & 50 & 55 & 61 & 60 & 77 & 58 & 57 & 54 & 41 \\
\hline Poland & 47 & 51 & 47 & 49 & 50 & 45 & 48 & 52 & 73 & 56 & 45 & 43 & 37 \\
\hline Portugal & 41 & 44 & 44 & 43 & 37 & 36 & 33 & 32 & 44 & 34 & 31 & 31 & 25 \\
\hline Romania & 8 & 11 & 27 & 30 & 31 & 30 & 31 & 29 & 32 & 29 & 29 & 28 & 27 \\
\hline Slovakia & 19 & 23 & 24 & 20 & 22 & 20 & 21 & 19 & 19 & 25 & 17 & 17 & 16 \\
\hline Slovenia & 29 & 29 & 24 & 26 & 25 & 23 & 20 & 20 & 23 & 29 & 23 & 22 & 21 \\
\hline Spain & 206 & 216 & 207 & 198 & 204 & 213 & 211 & 208 & 256 & 192 & 184 & 151 & 136 \\
\hline Sweden & 16 & 15 & 17 & 21 & 22 & 104 & 103 & 103 & 101 & 103 & 99 & 92 & 78 \\
\hline UK & 191 & 196 & 200 & 195 & 195 & 197 & 204 & 206 & 257 & 203 & 190 & 170 & 148 \\
\hline
\end{tabular}

Appendix 1 presents the annual number of banks (commercial and saving banks) for each EU country included in our sample. All data are sourced from the IBCA-BankScope 2008 CD.

Appendix 2 . Data Envelopment Analysis (DEA)

DEA was originally presented in Charles et al. (1978), assuming constant returns to scale, which can be accepted as optimal, but only in the long run. Later, Banker et al. (1984) introduced an additional convexity constraint $(\lambda)$ and allowed for variable returns to scale. Following also Coelli et al. (1998), Thanassoulis (2001) and Thanassoulis et al. (2007), we can assume that at any time $\mathrm{t}$, there are $\mathrm{N}$ decision-making units (DMUs) that use a set of $\mathrm{X}$ inputs $\left(X=x_{1}, x_{2}, \ldots, x_{k}\right)$ to produce a set of $Y$ outputs $\left(Y=y_{1}, y_{2}, \ldots, y_{m}\right)$, thus obtaining the DEA input-oriented efficiency measure of every $i$ DMU, solving the following optimization problem: 


$$
\begin{aligned}
& \min _{\theta, \lambda} \theta_{i} \\
& \text { s.t. } \quad \sum_{\mathrm{r}=1}^{\mathrm{N}} \mathrm{y}_{\mathrm{mr}}^{\mathrm{t}} \lambda_{r}^{t} \geq y_{m i}^{t} ; \sum_{\mathrm{r}=1}^{\mathrm{N}} \mathrm{x}_{\mathrm{kr}}^{\mathrm{t}} \lambda_{r}^{t} \leq \theta_{i} x_{k i}^{t} ; \lambda_{r}^{t} \geq 0 ; \sum_{\mathrm{r}=1}^{\mathrm{N}} \lambda_{r}^{t}=1
\end{aligned}
$$

The DEA approach provides, for every $i$ decision-making unit (DMU, here every country's banking sector), a scalar efficiency score $\left(\theta_{\mathrm{i}} \leq 1\right)$. If $\theta_{\mathrm{i}}=1$, the DMU lies on the efficient frontier and will be considered an efficient unit. On the contrary, if $\theta_{\mathrm{i}}<1$, the DMU lies below the efficient frontier and will be considered an inefficient unit; moreover, $\left(1-\theta_{\mathrm{i}}\right)$ will always be the measure of its inefficiency.

In the present study, the data are sourced from the IBCA-BankScope $2008 \mathrm{CD}$ and the sample comprises annual data from the consolidated accounts of the commercial and savings banks of 27 EU countries between 1996 and 2008.

For the DEA estimates, we define the outputs and the input prices of the cost function, using the following variables:

Outputs:

1. Total loans $=$ natural logarithm of the loans

2. Total securities $=$ natural logarithm of the total securities

3. Other earning assets $=$ natural logarithm of the difference between the total earning assets and the total loans

Inputs:

1. Price of borrowed funds = natural logarithm of the ratio interest expenses over the sum of deposits

2. Price of physical capital $=$ natural logarithm of the ratio non-interest expenses over fixed asset

3. Price of labour = natural logarithm of the ratio personnel expenses over the number of employees

\section{Copyright Disclaimer}

Copyright reserved by the author(s).

This article is an open-access article distributed under the terms and conditions of the Creative Commons Attribution license (http://creativecommons.org/licenses/by/3.0/). 